

\title{
Performance of Large Seeded Faba Bean Genotypes for Yield and Related Agronomic Traits in Different Parts of Ethiopia.
}

\author{
Mesfin Tadele ${ }^{1 *}$, Mussa Jarso ${ }^{1}$, Sisay Argaye ${ }^{1}$, Asnakech Tekalign ${ }^{1}$, Nigat Tilahun ${ }^{1}$, \\ Wondafrash Mulugetal, Aliy Robsa ${ }^{2}$, Deressa Tesfaye ${ }^{2}$, Kedir Yimam $^{2}$, Yechalew Silesh ${ }^{3}$, \\ Masresha Yirga ${ }^{3}$, Bulti Merga ${ }^{4}$,Demelash Basa ${ }^{5}$ \& Jemal Esmael ${ }^{6}$ \\ ${ }^{1}$ Ethiopian Institute of Agricultural Research, Holetta Agricultural Research Center, P.O. Box:2003, Addis Ababa, Ethiopia. \\ ${ }^{2}$ Ethiopian Institute of Agricultural Research, Kulumsa Agricultural Research Center, P.O. Box: 489, Asela, Ethiopia. \\ ${ }^{3}$ Ethiopian Institute of Agricultural Research, Jimma Agricultural Research Center, P.O. Box: 192, Jimma, Ethiopia. \\ ${ }^{4}$ School of Plant Science, Haramaya University, P.O. Box 138, Dire Dawa, Ethiopia. \\ ${ }^{5}$ Southern Agricultural Research Institute, Areka Agricultural Research Center, P.O. Box: 79, Areka, Ethiopia. \\ ${ }^{6}$ Amhara Regional Agricultural Research Institute, P. O. Box 257, Bahir Dar, Ethiopia. \\ ORCID ID: https://orcid.org/0000-0003-4909-117X ; Correspondent, Email: mesfintadele64@ gmail.com
}

Article DOI: https://doi.org/10.37284/eajab.4.1.486

\section{Date Published: ABSTRACT}

29 November 2021 Faba bean (Vicia faba L.) is a high value crop in Ethiopia and has versatile uses. The national faba bean breeding program concentrates on the three major traits (grain yield, disease resistance and seed size) of the crop for varietal Keywords: release for commercial production. Hence, ten faba bean genotypes were evaluated at Adet, Areka, Bekoji, Haramaya, Holetta and Jimma during the main cropping seasons of 2018 and 2019 using a randomized complete block design with four replications with the objectives to select the genotype with

Disease Resistance,

Major Traits,

Grain Yield, best performance in terms of important agronomic traits like grain yield, disease resistance, large seed size and other desirable agronomic traits for high potential production areas in Ethiopia. The combined analysis of variance across locations revealed that there is highly significant $(\mathrm{P}<0.01)$ variation among the tested genotypes for grain yield, 1000-seeds weight, number of pods per plant, and days to $90 \%$ physiological maturity. The genotype EH011089-3 showed better performance than the tested genotypes having comparable grain yield performance (3803 kgha-1) with the two standard checks, Numan and Gora (3790 and 3897 kgha-1, respectively) while it had the highest 1000-seeds weight (1065 g) compared to the two standard checks, Numan and Gora (937 $\mathrm{g}$ and $786 \mathrm{~g}$, respectively), i.e., $13.7 \%$ and $35.5 \%$ advantage, over the two standard checks, respectively. Additionally, EH011089-3 had better resistance for chocolate spot and rust diseases. Therefore, EH011089-3 was the best over the tested varieties and breeding lines. Genotype EH011089-3 is recommended for varietal release for commercial production all over in Ethiopia.

\section{APA CITATION}

Tadele, M., Jarso, M., Argaye, S., Tekalign, A., Tilahun, N., Mulugeta, W., Robsa, A., Tesfaye, D., Yimam, K., Silesh, Y., Yirga, M., Merga, B., Basa, D., \& Esmael, J. (2021 Performance of Large Seeded Faba Bean Genotypes for Yield and Related

1 | This work is licensed under a Creative Commons Attribution 4.0 International License. 
Agronomic Traits in Different Parts of Ethiopia. East African Journal of Agriculture and Biotechnology, 4(1), 1-11. https://doi.org/10.37284/eajab.4.1.486

\section{CHICAGO CITATION}

Tadele, Mesfin, Mussa Jarso, Sisay Argaye, Asnakech Tekalign, Nigat Tilahun, Wondafrash Mulugeta, Aliy Robsa, Deressa Tesfaye, Kedir Yimam, Yechalew Silesh, Masresha Yirga, Bulti Merga, Demelash Basa, and Jemal Esmael 2021. "Performance of Large Seeded Faba Bean Genotypes for Yield and Related Agronomic Traits in Different Parts of Ethiopia". East African Journal of Agriculture and Biotechnology 4 (1), 1-11. https://doi.org/10.37284/eajab.4.1.486.

\section{HARVARD CITATION}

Tadele, M., Jarso, M., Argaye, S., Tekalign, A., Tilahun, N., Mulugeta, W., Robsa, A., Tesfaye, D., Yimam, K., Silesh, Y., Yirga, M., Merga, B., Basa, D. and Esmael, J. (2021) "Performance of Large Seeded Faba Bean Genotypes for Yield and Related Agronomic Traits in Different Parts of Ethiopia”, East African Journal of Agriculture and Biotechnology, 4(1), pp. 1-11. doi: 10.37284/eajab.4.1.486.

\section{IEEE CITATION}

M. Tadele et al "Performance of Large Seeded Faba Bean Genotypes for Yield and Related Agronomic Traits in Different Parts of Ethiopia", EAJAB, vol. 4, no. 1, pp. 1-11, Nov. 2021.

\section{MLA CITATION}

Tadele, Mesfin, Mussa Jarso, Sisay Argaye, Asnakech Tekalign, Nigat Tilahun, Wondafrash Mulugeta, Aliy Robsa, Deressa Tesfaye, Kedir Yimam, Yechalew Silesh, Masresha Yirga, Bulti Merga, Demelash Basa, and Jemal Esmael "Performance of Large Seeded Faba Bean Genotypes for Yield and Related Agronomic Traits in Different Parts of Ethiopia". East African Journal of Agriculture and Biotechnology, Vol. 4, no. 1, Nov. 2021, pp. 1-11, doi:10.37284/eajab.4.1.486.

\section{NTRODUCTION}

Faba bean (Vicia faba L.) has a wide range of adaptability to different soils which enables it to perform better under climate change due to its unique ability to excel under most types of climatic conditions (Singh et al., 2013). It is an important pulse crop in Ethiopia that can grow at an altitude ranging from 1800 to 3000 meter above sea level and annual rainfall of 700 to $1100 \mathrm{~mm}$ (Mussa and Gemechu, 2006). Currently, faba bean occupies $30 \%$ of the total area cultivated for pulses and $35 \%$ of the total annual pulse production in Ethiopia (CSA, 2019/20). Faba bean is a multipurpose crop used as human food, animal feed and rotation with cereals and other crops (Mussa and Gemechu, 2006; Tadele, 2019). It is an important component of sustainable farming system in Ethiopia (Tamene et al., 2015).

Despite its importance, the national average productivity of this crop is about 2.16 tha $^{-1}$ in Ethiopia (CSA, 2019/20), which is lower than its potential productivity in Egypt and United Kingdom 3.47 and 3.83 tha $^{-1}$, respectively (FAOSTAT, 2018). The low average yield of faba bean in Ethiopia is resulted by its susceptibility to biotic and abiotic stresses, poor cultural practices and use of local varieties (Keneni et al., 2016). However, improved faba bean varieties are preferred by farmers for their high grain yield, larger seed size, tolerance to water logging and other stresses (Asnakech et al., 2016). Generally, farmers prefer varieties with high and stable yields with desirable agronomic traits.

To maintain high agricultural productivity, the development of varieties with high grain yield potential is the ultimate goal of national faba bean improvement program. Recently, faba bean breeding in Ethiopia mainly focuses on varietal development with improved grain yield, large seed size, resistance to major diseases (chocolate spot and faba bean gall), weed resistance (Orobanche spp.) and tolerant to abiotic constraints (waterlogging, soil acidity, and drought (Keneni et al., 2016). In Ethiopia, the hybridization program used inbred lines introduced from ICARDA such as ILB 938, ILB 4726, ILB 4615, ILB 4725, and ILB 4709 as sources of resistance to chocolate spot and large seed size (Keneni et al., 2006); Atoma was then used for large seed size. Therefore, it is necessary to identify potential germplasms from the locally available faba bean landraces and inbred lines for genetic sources in the breeding programmes. Furthermore, the recently developed cultivars should have better agronomic performance than previously released varieties and have a broad adaptation across Ethiopia. Therefore, this research was conducted with the objective to evaluate the grain yield and other agronomic performances of faba bean genotypes across a broad range of environments. 


\section{MATERIALS AND METHODS}

\section{Description of Testing Sites and Planting Materials}

The experiment was carried out in 2018 and 2019 cropping seasons at six locations, Holetta, Bekoji, Jimma, Haramaya, Adet and Areka that represent different faba bean growing agro-ecological zones of Ethiopia (Table 1). The test locations and years were considered as a separate environment, making 10 test environments. Ten faba bean genotypes (8 advanced lines and 2 released varieties) collected from Holetta Agricultural Research Centre were used for this experiment (Table 2).

Table 1: Description of the six test locations used to evaluate 10 genotypes in 2018 and 2019 main cropping season

\begin{tabular}{|c|c|c|c|c|c|c|c|}
\hline \multirow[t]{2}{*}{ Location } & \multirow[t]{2}{*}{ Year } & \multicolumn{2}{|c|}{ Geographical position } & \multirow{2}{*}{$\begin{array}{l}\text { Altitude } \\
\text { (m.a.s.l.) }\end{array}$} & \multirow{2}{*}{$\begin{array}{l}\text { Annual } \\
\text { rainfall } \\
(\mathbf{m m})\end{array}$} & \multicolumn{2}{|c|}{$\operatorname{Temp}\left({ }^{\circ} \mathrm{C}\right)$} \\
\hline & & Latitude (N) & $\begin{array}{l}\text { Longitude } \\
\text { (E) }\end{array}$ & & & Min. & Max. \\
\hline Holetta & 2018 & $09^{\circ} 00^{\prime}$ & $38^{\circ} 30^{\prime}$ & 2400 & 1035 & 6.6 & 24.1 \\
\hline Bekoji & 2018,2019 & $07^{\circ} 32^{\prime}$ & $39^{\circ} 15^{\prime}$ & 2780 & 1010 & 7.9 & 16.6 \\
\hline Jimma & 2018,2019 & $07^{\circ} 24^{\prime} 59^{\prime \prime}$ & $37^{\circ} 00^{\prime} 00^{\prime \prime}$ & 2300 & 1200 & 20.0 & 25.0 \\
\hline Haramaya & 2018,2019 & $09^{\circ} 42^{\prime} 32^{\prime \prime}$ & $42^{\circ} 03^{\prime} 85^{\prime \prime}$ & 2002 & 760 & 8.3 & 23.4 \\
\hline Adet & 2019 & $11^{\circ} 16^{\prime}$ & $37^{\circ} 29^{\prime}$ & 2216 & 1250 & 9.2 & 25.5 \\
\hline Areka & 2018,2019 & $07^{\circ} 06^{\prime} 97^{\prime \prime}$ & $37^{\circ} 69^{\prime} 72^{\prime \prime}$ & 1780 & 1438 & 14.2 & 26.2 \\
\hline
\end{tabular}

m.a.s.l. = meter above sea level, min=minimum, max $=$ maximum

Table 2: Description of 10 Faba bean genotypes evaluated at 10 environments during the 2018 and 2019 main cropping season

\begin{tabular}{llll}
\hline No. & Genotype & Pedigree & Status \\
\hline 1 & Numan $^{\star}$ & EH99037-5 × ILB1563 & Released (2016) \\
2 & Gora $^{\bullet}$ & R878-3 $\times$ ILB4914-1 & Released (2012) \\
3 & EH011070-1 & EK02006-2-1 × Atoma & Advanced line \\
4 & EH011040-1 & EH00016-2 × ILB4726 & Advanced line \\
5 & EH011001-1 & EK02016-2-1 × ILB938 & Advanced line \\
6 & EH011093-2 & EK01004-2-1 × EK01002-1-1 & Advanced line \\
7 & EH011089-3 & EKLS01001-5-1 × EK01002-1-1 & Advanced line \\
8 & EH011049-2 & EK02006-2-1 × ILB1563 & Advanced line \\
9 & EH011037-2 & EH00014-3-1 × ILB4726 & Advanced line \\
10 & EH011029-2 & EK01004-2-1 × ILB4726 & Advanced line \\
\hline
\end{tabular}

- standard checks

\section{Experimental Design and Data Collection}

The treatments were arranged in a randomized complete block design with four replications at each environment location. The plots were 4 rows of $4 \mathrm{~m}$ length with spacing of $40 \mathrm{~cm}$ and $10 \mathrm{~cm}$ between rows and plants, respectively. The space between blocks and plots were $1.5 \mathrm{~m}$ and $0.6 \mathrm{~m}$, respectively. Blended fertilizer NPS in the form of $19 \mathrm{~N}-38 \mathrm{P}_{2} \mathrm{O}_{5}-7 \mathrm{~S}$ was applied at planting at all locations to each plot at the rate of $121 \mathrm{~kg} \mathrm{ha}^{-1}$ in the form of NPS. All agronomic practices were applied uniformly to the entire experimental area in each environment.
All agronomic data at all locations were recorded either on whole plot or 5 random sample plant bases. Accordingly, days to 50\% flowering (DTF) and days to $90 \%$ physiological maturity (DTM), Disease (chocolate spot and rust) (1-9 scale) and grain yield data was taken from net plot $3.2 \mathrm{~m}^{2}$ from the central two rows and adjusted to standard grain moisture content of pulses $(10 \%)$ then converted into $\mathrm{kg} \mathrm{ha}^{-1}$. Plant height (PHT), number of pods per plant (PPP) and number of seeds per pod (SPP) were recorded on 5 plant bases. Thousand seed weight (TSW) from randomly selected 1000 seeds from each plot. Grain yield data were adjusted to a constant

3 This work is licensed under a Creative Commons Attribution 4.0 International License. 
moisture level of pulses grains (10\%). The severity of chocolate spot and rust diseases were recorded using the scale: $1=$ no disease symptoms or very small spots (highly resistant), $3=$ few small disease lesions (resistance), $5=$ some coalesced lesions, with some defoliation (moderately resistant), $7=$ large coalesced sporulating lesions, $50 \%$ defoliation some dead plants (susceptible), $9=$ extensive, heavy sporulation, stem gridling, blackening and death of more than $80 \%$ of plants (heavily susceptible) (Bernier et al. (1993). For data analysis, grain yield was converted to $\mathrm{kg} \mathrm{ha}^{-1}$ and the mean data of 5 randomly sampled plants were used.

\section{Statistical Analysis}

Data on grain yield and other agronomic traits were subjected to analysis of variance for a randomized complete block design as per the procedure of Gomez and Gomez (1984), using SAS software version 9.3 statistical software package (SAS Institute, 2012). Variance homogeneity was tested and combined analysis of variance was employed using the SAS PROC GLM (General Linear Model) procedure to partition the total variation into components due to genotype $(\mathrm{G})$, environment $(\mathrm{E})$ and $\mathrm{G} \times \mathrm{E}$ interaction effects. The genotypes were treated as a fixed effect while environment as a random effect. Mean separation at 5\% probability level was done using Least Significant Difference (LSD), based on significant genotype differences. The total variability for the traits was quantified using pooled analyses of variance across environments using the following model:

$Y_{i j k}=\mu+G_{i}+E_{j}+G_{i j}+B_{k(j)}+\epsilon_{i j k}$

where $Y_{i j k}$ is an observed value of genotype ${ }_{i}$ in block $_{k}$ of environment ${ }_{j} ; \mu$ is a grand mean; $G_{i}$ is effect of genotype $i ; E_{j}$ is an environmental effect; $G E_{i j}$ is the interaction effect of genotype ${ }_{i}$ with environment ${ }_{j} ; B_{k(j)}$ is the effect of block ${ }_{k}$ in environment ${ }_{j} ; \epsilon_{i j k}$ is an error effect of genotype ${ }_{i}$ in block ${ }_{k}$ of environment ${ }_{j}$.

\section{RESULTS AND DISCUSSION}

\section{Analysis of Variance}

The pooled analysis of variance (ANOVA) for 10 traits over environments revealed highly significant $(P<0.01)$ difference for genotypes $(\mathrm{G})$, environments $(\mathrm{E})$ and $\mathrm{G} \times \mathrm{E}$ interaction effects for most of the traits studied, including days to $50 \%$ flowering (DTF), days to $90 \%$ maturity (DTM), plant height (PHT), number of pods per plant (PPP), grain yield (GY), 1000seeds weight (TSW), chocolate spot (CS) and grain filling period (GFP). Conversely, number of seeds per pod (SPP) was non-significantly different (Table 3), indicating lack of sufficient genetic variation for these traits existed among the tested genotypes. A previous study on Ethiopian faba bean germplasms also indicated that number of seeds per pod repeatedly showed nonsignificant differences among evaluated genotypes (Million and Habtamu, 2012; Tadele et al., 2020). Conversely it was reported significantly different among genotypes for number of seeds per pod (Asnakech et al., 2020).

Mean squares (Table 3) from pooled analysis of variance due to environments (E) (year by location) were highly significant $(P<0.01)$ for all traits under consideration, indicating that there were visible differences between the 10 environments which are significant enough to differentiate the genetic performance of evaluated faba bean genotypes. The mean squares of grain yield due to genotypes (G) were highly significantly different, indicating the existence of enough genetic variability for grain yield among tested genotypes. The $\mathrm{G} \times \mathrm{E}$ (two-way interaction) had significant effects on most of the traits except number of seeds per pods and rust reaction (Table 3). The interaction effect of $\mathrm{G} \times \mathrm{E}$ being significantly different on most of the traits over environments indicated the differential performance of genotypes in different environments for the traits under consideration. In agreement with this result, significant genotypic differences in faba bean genotypes were reported for days to flowering, plant height, number of pod per plant and 1000 seeds weight (Kumar et al., 2017, Mesfin et al., 2019). Likewise, significant effects of environment/location on 1000 seeds weight of faba bean have been reported (Mesfin et al., 2019; Ashenafi and Mekuria, 2015). In line with this, different reports confirmed the presence of significant $\mathrm{G} \times \mathrm{E}$ interaction effects on grain yield of faba bean in different sets of environments in Ethiopia (Mesfin et al., 2019; Tamene et al., 2015; Million and Habtamu, 2012). In disagreement with this result, non-significant $G$ $\times$ E interaction effects for chocolate spot disease due to environmental variance were reported (Tamene et al., 2015; Asnakech et al., 2017).

4 | This work is licensed under a Creative Commons Attribution 4.0 International License. 
Selection of best performing genotypes under one set of environments with significant $\mathrm{G} \times \mathrm{E}$ (high $\mathrm{G} \times \mathrm{E})$ may not perform consistently under different sets of environments due to rank order change of genotypes across environments (Mesfin et al., 2020). This implies that recommendation of genotypes for all locations is hardly possible based on better performance of genotypes at one environment. Likewise, previously it was reported that, under significant $\mathrm{G} \times \mathrm{E}$ interaction, selection of genotypes that perform best under one set of environment becomes impractical to all sets of environments (Keneni et al., 2015; Mesfin et al., 2019). When genotypes perform consistently across locations, breeders are able to effectively evaluate germplasms with a minimum cost in a few locations for ultimate use of the resulting varieties across wider geographic areas (Ceccarelli, 1997). However, it is not possible to determine the performance consistency/inconsistency of genotypes in the early stages of cultivar development.

Relatively larger coefficients of variation (CV) values (> 25\%) for chocolate spot (CS) and rust may be related to the variation in the disease reaction of the tested genotypes or favorable/unfavorable environmental condition for disease incidence or the combined effects of the two. On the other hand, values for the coefficient of determination $\left(\mathrm{R}^{2}\right)$ of the experiment varied among traits, ranging from 0.64 for CS to 0.98 for DTM, indicating that, the analysis of variance model explained much of the variation in the experiment (Table 4). The result suggested the presence of considerable variation among genotypes for most of the traits studied. This also indicated the presence of ample scope for selection to improve different quantitative traits of Faba bean.

Table 3: Mean squares of 10 traits from the analysis of variance of 10 Faba bean genotypes evaluated at 10 environments (year by location) in 2018 and 2019 main cropping season

\begin{tabular}{lllllll}
\hline & Mean squares & & & & \\
\cline { 2 - 5 } Traits & Block/Env. (30) & Env. $(\mathbf{E})(\mathbf{9})$ & $\mathbf{G e n o .}(\mathbf{G})(\mathbf{9})$ & $\mathbf{G} \times \mathbf{E}(\mathbf{8 1})$ & Error $(\mathbf{2 7 0})$ & CV \\
\hline DTF & $7.00^{*}$ & $1450.45^{* *}$ & $247.72^{* *}$ & $24.77^{* *}$ & 4.24 & 3.55 \\
DTM & $4.56^{* *}$ & $6696.83^{* *}$ & $81.18^{* *}$ & $16.57^{* *}$ & 2.65 & 1.15 \\
GFP & $8.30^{\text {ns }}$ & $6654.50^{* *}$ & $230.14^{* *}$ & $42.72^{* *}$ & 6.22 & 2.98 \\
PHT & $228.38^{* *}$ & $19416.45^{* *}$ & $1717.25^{* *}$ & $193.99^{* *}$ & 86.77 & 7.10 \\
PPP & $10.05^{* *}$ & $199.26^{* *}$ & $42.11^{* *}$ & $12.69^{* *}$ & 5.49 & 20.35 \\
SPP & $0.24^{\text {ns }}$ & $5.24^{*}$ & $0.33^{\text {ns }}$ & $0.23^{\text {ns }}$ & 0.13 & 12.87 \\
CS & $2.46^{* *}$ & $18.44^{* *}$ & $1.01^{\text {ns }}$ & $1.87^{* *}$ & 1.00 & 28.16 \\
Rust & $0.89^{\text {ns }}$ & $62.69^{* *}$ & $1.26^{\text {ns }}$ & $0.71^{\text {ns }}$ & 0.77 & 29.31 \\
TSW & $3325.04^{\text {ns }}$ & $595137.58^{* *}$ & $457592.30^{* *}$ & $26778.22^{* *}$ & 4258.67 & 6.62 \\
YLD & $352945.80^{* *}$ & $18294927.80^{* *}$ & $1660300.50^{* *}$ & $858085.50^{* *}$ & 121453.10 & 9.66 \\
\hline
\end{tabular}

${ }^{*}{ }^{* *}$ Significant at 0.05 and 0.01 probability level, respectively, ${ }^{n s}$ non-significant, figures in parenthesis indicate degrees of freedom. DTF, DTM, GFP= number of days to 50\% flowering $90 \%$ maturity and grain filling period, respectively; $P H T=$ plant height $(\mathrm{cm}) ; P P P$ and $S P P=$ number of pods per plant and seeds per pod; $C S=$ chocolate spot disease (1-9 scale); TSW=1000 seeds weight (g) and $Y L D=$ grain yield in $\mathrm{kg} / \mathrm{ha}$

\section{Mean Performance of Genotypes}

\section{Phenological and Development of Genotypes}

The genotypes had days to 50\% flowering ranged between 55 days (EH011089-3 and EH011049-2) and 62 days (EH011029-2) with an overall mean of 58 days over the ten test environments. The genotypes showed significantly earlier flowering (8 days) for EH011089-3 and EH011049-2 compared to the late flowering EH011029-2 (Table 4).

Days to $90 \%$ maturity of genotypes ranged between 140 days (EH01193-2 and EH011089-3) and 144 days (EH011040-1) with the overall mean value of 142 days across ten test environments. A total of four genotypes would be considered earlier maturing and significantly different from other genotypes over environments (Table 4). The genotypes had mean value of 87.3 days for grain filling period with the range spanning between 79

5 | This work is licensed under a Creative Commons Attribution 4.0 International License. 
and 88 days for EH011037-2 and EH01149-2, respectively over environments (Table 4).

The observed variation among genotypes for days to $50 \%$ flowering and $90 \%$ maturity over environments may be due to the inherent traits of genotypes and the influence of environments. Therefore, short grain filling period resulted from short days to flowering and maturity which is an advantage if any terminal moisture stress encountered in the environment(s). Likewise, it was reported that faba bean genotypes took 61 65 days for days to $50 \%$ flowering and 130-143 days to $90 \%$ maturity (Tewodros et al., 2015), and 57 to 63 and 137 to 146 days to $50 \%$ flowering and days to $90 \%$ maturity, respectively (Million, 2012). Partially in agreement with this finding Million (2012) and Tekle et al. (2016), reported grain filling period of faba bean genotypes that ranged from 78 to 87 and 75 to 88 days, respectively.

The genotypes had overall mean plant height $(\mathrm{PH})$ at maturity of $131 \mathrm{~cm}$ with a range of 120 to 138 $\mathrm{cm}$ for EH011037-2 and EH011089-3, respectively over environments with significant difference among the mean values of genotypes (Table 4). The significant difference in plant height indicated existence of variation among evaluated genotypes which is mainly attributed to genotype and their growing environment. In agreement with this result a plant height of 119 to $137 \mathrm{~cm}$ reported for faba bean (Million, 2012). In contrast, previously a plant height of 143 to $167 \mathrm{~cm}$ reported (Dereje et al., 2019).

\section{Pods per Plant and Thousand Seeds Weight of Genotypes}

The genotypes had mean number of pods per plant (PPP) that ranged between 10 (EH011037-2, EH011029-2) and 13 (Gora) with an overall mean value of 11.5. The PPP of genotypes were varied by environment, genotype, and their interaction. The genotype with the PPP had the highest grain yield. This result suggested that increase in PPP directly related with increase in grain yield. The result agreed with the previous reports of (Million, 2012), and (Dereje et al., 2019), who reported 6 to 10 and 7 to 10 pods per plant, respectively. In contradiction to this study result, Tekle et al. (2016), reported 19 to 22 PPP. Faba bean can suffer high incidence of flower abortions and consequent reduction in the number of pods per plant.

The tested genotypes showed better 1000-seeds weight (TSW) that ranged from 851g (EH0110011) to $1107 \mathrm{~g}$ (EH011040-1), excluding the standard checks (Numan and Gora). The genotypes had a TSW advantage of $8-41 \%$ compared to Gora and $2-18 \%$ over the recently released cultivar Numan (Table 4). The increase in TSW of the test genotypes is due to the attention given for this trait in the national breeding program and presence of superior parent materials to improve this trait. Previously, it was reported $34-70 \%$ seed size increase in faba bean varieties released after 2006 as compared to CS20DK and NC58 (Tamene et al., 2015). Similarly, seed size increase resulted in response to meet the current export-market demand for large seed size at national and international levels (Keneni et al., 2016). Moreover, the seed size of faba bean dramatically increased from the first released variety (CS20DK, 1977) to the most recent release (Numan, 2016), (Tadele, 2019).

On the other hand, variations in TSW across environments were due to the genetic potential of the test genotypes rather than test environments because there were no rank order changes of the lowest and highest TSW of genotypes (results not shown). The result implied that TSW was less affected by test $\mathrm{s}$ as compared to the other traits. A previous report indicated that TSW in faba bean was less variable than grain yield (Tamene et al., 2015). Likewise, Abebe and Tolera (2014), also reported that TSW was not changed as a response of lime application under acidic soil.

Table 4: Combined mean grain yield and other agronomic parameters for 10 faba bean genotypes across 10 environments (year by location) tested in 2018 and 2019 main cropping seasons

\begin{tabular}{llllllllllll}
\hline No & Genotype & DTF & DTM & GFP & PH & PPP & SPP & CS & Rust & TSW & YLD \\
\hline $\mathbf{1}$ & Numan & $57^{\mathrm{c}}$ & $142^{\mathrm{c}}$ & $84^{\mathrm{b}}$ & $135^{\mathrm{ab}}$ & $12^{\mathrm{ab}}$ & 3 & $3.5^{\mathrm{bcd}}$ & 3.6 & $937^{\mathrm{d}}$ & $3790^{\mathrm{ab}}$ \\
$\mathbf{2}$ & Gora & $56^{\mathrm{de}}$ & $143^{\mathrm{a}}$ & $87^{\mathrm{a}}$ & $137^{\mathrm{a}}$ & $13^{\mathrm{a}}$ & 3 & $3.3^{\mathrm{cd}}$ & 2.7 & $787^{\mathrm{f}}$ & $3897^{\mathrm{a}}$ \\
$\mathbf{3}$ & EH011070-1 & $57^{\mathrm{cd}}$ & $141^{\mathrm{c}}$ & $84^{\mathrm{b}}$ & $124^{\mathrm{c}}$ & $11^{\mathrm{d}}$ & 3 & $3.7^{\mathrm{abc}}$ & 3.0 & $1055^{\mathrm{c}}$ & $3720^{\mathrm{b}}$ \\
$\mathbf{4}$ & EH011040-1 & $60^{\mathrm{b}}$ & $144^{\mathrm{a}}$ & $84^{\mathrm{b}}$ & $123^{\mathrm{c}}$ & $11^{\mathrm{d}}$ & 3 & $3.2^{\mathrm{d}}$ & 2.7 & $1107^{\mathrm{a}}$ & $3417^{\mathrm{cd}}$ \\
\hline
\end{tabular}

6 | This work is licensed under a Creative Commons Attribution 4.0 International License. 


\begin{tabular}{|c|c|c|c|c|c|c|c|c|c|c|c|}
\hline No & Genotype & DTF & DTM & GFP & PH & PPP & SPP & CS & Rust & TSW & YLD \\
\hline 5 & EH011001-1 & $60^{\mathrm{b}}$ & $143^{\mathrm{a}}$ & $82^{c}$ & $136^{\mathrm{a}}$ & $12^{\mathrm{bc}}$ & 3 & $3.2^{\mathrm{d}}$ & 2.8 & $851^{\mathrm{e}}$ & $3537^{c}$ \\
\hline 6 & ЕH011093-2 & $57^{\mathrm{cd}}$ & $140^{\mathrm{d}}$ & $83^{c}$ & $131^{\mathrm{b}}$ & $12^{\mathrm{bc}}$ & 3 & $3.6^{\mathrm{a}-\mathrm{d}}$ & 3.1 & $955^{\mathrm{d}}$ & $3694^{\mathrm{b}}$ \\
\hline 7 & ЕH011089-3 & $55^{\mathrm{e}}$ & $140^{\mathrm{d}}$ & $84^{\mathrm{b}}$ & $138^{\mathrm{a}}$ & $12^{\mathrm{bc}}$ & 3 & $3.4^{\mathrm{cd}}$ & 2.9 & $1065^{\mathrm{bc}}$ & $3803^{\mathrm{ab}}$ \\
\hline 8 & ЕH011049-2 & $55^{\mathrm{e}}$ & $143^{\mathrm{a}}$ & $88^{\mathrm{a}}$ & $137^{\mathrm{a}}$ & $11^{\mathrm{cd}}$ & 3 & $3.9^{\mathrm{a}}$ & 3.1 & $952^{\mathrm{d}}$ & $3541^{\mathrm{c}}$ \\
\hline 9 & ЕH011037-2 & $62^{\mathrm{a}}$ & $141^{\mathrm{c}}$ & $79^{d}$ & $120^{\mathrm{c}}$ & $10^{\mathrm{d}}$ & 3 & $3.5^{\mathrm{bcd}}$ & 3.0 & $1053^{\mathrm{c}}$ & $3394^{\text {cd }}$ \\
\hline 10 & EH011029-2 & $60^{\mathrm{b}}$ & $142^{\mathrm{b}}$ & $82^{c}$ & $131^{\mathrm{b}}$ & $10^{\mathrm{d}}$ & 3 & $3.8^{\mathrm{ab}}$ & 3.1 & $1089^{\mathrm{ab}}$ & $3280^{\mathrm{d}}$ \\
\hline & Mean & 58.0 & 142.0 & 83.7 & 131.1 & 11.5 & 2.8 & 3.51 & 3.00 & 985.2 & 3607.2 \\
\hline & CV\% & 3.7 & 1.2 & 2.98 & 7.7 & 21.0 & 13.4 & 23.0 & 24.7 & 6.6 & 9.7 \\
\hline & $\operatorname{LSD}(5 \%)$ & 0.93 & 0.78 & 1.16 & 4.40 & 1.10 & NS & 0.40 & NS & 28.5 & 152.5 \\
\hline & $\mathrm{R}^{2}$ & 0.92 & 0.98 & 0.97 & 0.87 & 0.65 & 0.62 & 0.64 & 0.77 & 0.90 & 0.89 \\
\hline
\end{tabular}

\section{Disease Reaction of Genotypes}

The overall mean chocolate spot (CS) reactions of genotypes over environments were between 3.2 for EH011040-1 and EH011001-1 to 3.9 for EH011049-2 with mean value of 3.51. The genotypes Gora, EH011040-1, EH011001-1 and EH011089-3 showed less susceptibility to chocolate spot with non-significant difference from other tested genotypes. Similarly, the mean rust reactions of genotypes over environments were between 2.7 for EH011040-1 and EH011001-1 to 3.6 for Numan with mean of 3.0. The genotypes Gora, EH011040-1, EH011001-1 and EH011089-3 showed less susceptibility to rust with non-significant difference from other genotypes except Numan (Table 4). The genotype Gora, EH011040-1, and EH011001-1 showed less susceptible to disease due the inherited disease resistance gene from their parents (ILB4914-1, ILB4726 and ILB938) (Table 2). The result indicated the presence of higher chance of selecting disease resistant genotypes for disease stress which is one of the faba bean production constraints in the study areas. Genotypes that become susceptible to chocolate spot and rust disease gave lower grain yield as compared to genotypes relatively resistant. Chocolate spot is the most widespread and destructive faba bean disease in Ethiopia, with estimated yield reductions of up to $68 \%$ on susceptible cultivars (Samuel et al., 2010). Chocolate spot is a major constraint of faba bean production in Ethiopia due to lack of disease resistant genotypes from the locally adapted varieties (Asnakech et al., 2017).

\section{Mean Grain Yield Performance of Genotypes}

The average grain yield $\left(\mathrm{kg} \mathrm{ha}^{-1}\right)$ of genotypes over environments ranged from 3280 to 3897 in which the lowest and highest grain yield was recorded for genotype EH011029-2 and Gora, respectively, with an overall genotype mean of $3607 \mathrm{~kg} \mathrm{ha}^{-1}$. The greatest mean grain yield was for the standard cultivar Gora followed by EH011089-3 (Table 4). The average environmental grain yield across genotypes ranged from lowest $2319.8 \mathrm{~kg} \mathrm{ha}^{-1}$ at Adet-2019 to the highest $4551.6 \mathrm{~kg} \mathrm{ha}^{-1}$ at Jimma-2019 (Table 5). The standard cultivar Gora ranked first at three of the 10 environments (Areka-2018, Jimma-2018, and Holetta-2018). Likewise, one best-performing pipeline genotype EH011089-3 ranked first at two environments (Adet-2019 and Bekoji-2019). Gora was the best yielding genotype $\left(5010 \mathrm{~kg} \mathrm{ha}^{-1}\right)$ in the highest-yielding environment (Holetta-2018), and EH011089-3 showed the best yield of $3075 \mathrm{~kg} \mathrm{ha}^{-1}$ in the lowest-yielding environment (Adet-2019) (Table 5 ). This differential yield ranking of genotypes across the test environments showed that the $G \times$ E interaction effect was of the crossover type and the rank order of genotypes were different in different environments. Similarly, differential grain yield performance of genotypes across different environments was reported in faba bean (Tamene et al., 2015).

$7 \mid$ This work is licensed under a Creative Commons Attribution 4.0 International License. 
East African Journal of Agriculture and Biotechnology, Volume 4, Issue 1, 2021

Article DOI: https://doi.org/10.37284/eajab.4.1.486

Table 5: Grain yield performance of 10 faba bean genotypes across 10 environments (year by location) in 2018 and 2019 main cropping season

\begin{tabular}{|c|c|c|c|c|c|c|c|c|c|c|c|}
\hline \multirow[b]{2}{*}{ No. } & \multirow[b]{2}{*}{ Genotype } & \multirow{2}{*}{$\frac{\text { Adet }}{2019}$} & \multicolumn{2}{|l|}{ Areka } & \multicolumn{2}{|l|}{ Bekoji } & \multicolumn{2}{|c|}{ Haramaya } & \multirow{2}{*}{$\begin{array}{l}\text { Holetta } \\
2018\end{array}$} & \multicolumn{2}{|l|}{ Jimma } \\
\hline & & & 2018 & 2019 & 2018 & 2019 & 2018 & 2019 & & 2018 & 2019 \\
\hline & & $2584^{b}$ & $3031^{b}$ & $3136^{\mathrm{bc}}$ & $3645^{\mathrm{a}}$ & $4323^{b c}$ & $4259^{a}$ & $4123^{a}$ & $4375^{\mathrm{cd}}$ & $4259^{b}$ & $4160^{d}$ \\
\hline 2 & Gora & $2568^{b}$ & $3700^{\mathrm{a}}$ & $3536^{\mathrm{ab}}$ & $3623^{\mathrm{a}}$ & $3949^{\text {de }}$ & $3806^{b c}$ & $3668^{\mathrm{ab}}$ & $5010^{\mathrm{a}}$ & $4932^{\mathrm{a}}$ & $4175^{d}$ \\
\hline 3 & EH011070-1 & $2505^{b c}$ & $3101^{\mathrm{ab}}$ & $3267^{\mathrm{abc}}$ & $3702^{\mathrm{a}}$ & $4054^{\text {cde }}$ & $3278^{d}$ & $3883^{\mathrm{ab}}$ & $4959^{\mathrm{ab}}$ & $3955^{b c}$ & $4496^{c}$ \\
\hline 4 & ЕH011040-1 & $2089^{\mathrm{cd}}$ & $3107^{a b}$ & $3231^{\mathrm{abc}}$ & $3528^{a}$ & $2999^{f g}$ & $4459^{a}$ & $2734^{\mathrm{de}}$ & $3860^{\mathrm{e}}$ & $3465^{d}$ & $4695^{\mathrm{bc}}$ \\
\hline 5 & EH01 1001-1 & $1864^{\mathrm{d}}$ & $2515^{b}$ & $3203^{b c}$ & $3373^{\mathrm{a}}$ & $3761^{\mathrm{e}}$ & $4151^{\mathrm{ab}}$ & $3090^{\mathrm{cd}}$ & $4120^{\mathrm{de}}$ & $4298^{b}$ & $4993^{\mathrm{a}}$ \\
\hline 6 & ЕH011093-2 & $2160^{\mathrm{bcd}}$ & $2966^{\mathrm{b}}$ & $3675^{\mathrm{a}}$ & $3735^{\mathrm{a}}$ & $4128^{\mathrm{cd}}$ & $4470^{\mathrm{a}}$ & $2629^{\mathrm{de}}$ & $4581^{\mathrm{a}-\mathrm{d}}$ & $3680^{\mathrm{cd}}$ & $4922^{\mathrm{ab}}$ \\
\hline 7 & ЕH011089-3 & $3075^{\mathrm{a}}$ & $2698^{b}$ & $3066^{c}$ & $3370^{\mathrm{a}}$ & $4870^{\mathrm{a}}$ & $4186^{\mathrm{ab}}$ & $3791^{\mathrm{ab}}$ & $4792^{\mathrm{abc}}$ & $3636^{\mathrm{cd}}$ & $4545^{\mathrm{c}}$ \\
\hline 8 & ЕH011049-2 & $1959^{d}$ & $2696^{\mathrm{b}}$ & $3210^{\mathrm{bc}}$ & $3681^{\mathrm{a}}$ & $4590^{\mathrm{ab}}$ & $3487^{\mathrm{cd}}$ & $3863^{\mathrm{ab}}$ & $4406^{\mathrm{cd}}$ & $3628^{\mathrm{cd}}$ & $3892^{\mathrm{d}}$ \\
\hline 9 & ЕH011037-2 & $2453^{b c}$ & $2987^{b}$ & $.3202^{\mathrm{bc}}$ & $2767^{\mathrm{b}}$ & $2862^{\mathrm{g}}$ & $4479^{a}$ & $3584^{\mathrm{bc}}$ & $3853^{\mathrm{e}}$ & $2844^{\mathrm{e}}$ & $4914^{\mathrm{ab}}$ \\
\hline \multirow[t]{5}{*}{10} & ЕH011029-2 & $1943^{\mathrm{d}}$ & $2594^{\mathrm{b}}$ & $3028^{c}$ & $3830^{\mathrm{a}}$ & $3168^{\mathrm{df}}$ & $2359^{\mathrm{e}}$ & $2362^{\mathrm{e}}$ & $4468^{\mathrm{bcd}}$ & $4325^{\mathrm{b}}$ & $4726^{\mathrm{abc}}$ \\
\hline & Grand Mean & 2319.8 & 2939.3 & 3255.3 & 3525.3 & 3870.3 & 3893.5 & 3372.8 & 4442.3 & 3902.1 & 4551.6 \\
\hline & $\mathrm{CV} \%$ & 9.0 & 15.5 & 9.4 & 9.8 & 5.3 & 7.0 & 10.4 & 7.9 & 8.2 & 4.5 \\
\hline & $\operatorname{LSD}(5 \%)$ & 427.4 & 660.2 & 446.3 & 503.7 & 300 & 394.9 & 521 & 510.8 & 466.3 & 295.9 \\
\hline & $\mathrm{R}^{2}$ & 0.83 & 0.58 & 0.47 & 0.63 & 0.94 & 0.89 & 0.80 & 0.67 & 0.82 & 0.82 \\
\hline
\end{tabular}

Mean values of the same category followed by different letters are significant at $p \leq 0.05$ level 


\section{CONCLUSION}

In general, all eight evaluated genotypes had lower grain yield than the two checks, except EH011089-3. EH011089-3 had comparable grain yield performance with the two standard checks, Numan and Gora that have 3790 and $3897 \mathrm{kgha}^{-1}$, respectively. Additionally, EH011089-3 has greater 1000-seeds weight than the two standard checks, Numan and Gora with a 1000-seeds weight advantage of $14 \%$ and $35 \%$, over the two standard checks, respectively. Furthermore, EH011089-3 ranked in the top third of all genotypes in well over half of the 10 test environments. Hence, genotype EH011089-3 had comparatively stable grain yield across the test environments. For these reasons, EH011089-3 is recommended for varietal release for commercial production.

\section{CONFLICTS OF INTEREST}

The authors declare that there is no conflict of interest.

\section{ACKNOWLEDGMENTS}

This work was part of the national faba bean breeding program financed by Ethiopian Institute of Agricultural Research. The authors would like to express their deepest gratitude to staff members of highland pulse breeding program of Holetta, Kulumsa, Jimma, Adet and Areka Agricultural Research Centres and Haramaya University for their valuable contribution for successful accomplishment of this research work.

\section{REFERENCES}

Abera, T., \& Abebe, Z. (2014). Effects of fertilizer rate, rhizobium inoculation and lime rate on seed yield of faba bean at Horro and Gedo highlands. WebPub J. Agric. Res, 2(4), 61-68.

Abera, T., \& Abebe, Z. (2014). Effects of fertilizer rate, rhizobium inoculation and lime rate on seed yield of faba bean at Horro and Gedo highlands. WebPub J. Agric. Res, 2(4), 61-68.

Asnakech T, Julia S, John D, Asnake F (2017) Analysis of genotype $\times$ environment interaction and stability for grain yield and chocolate spot (Botrytis fabae) disease resistance in faba bean (Vicia faba L).
Australian journal of crop science, 11(10):1228-1235.

Asnakech T, Julia S, John D, Asnake F (2017) Analysis of genotype $\times$ environment interaction and stability for grain yield and chocolate spot (Botrytis fabae) disease resistance in faba bean (Vicia faba L). Australian journal of crop science, 11(10):1228-1235.

Bernier, C. C., Hanounik, S. B., Hussein, M. M., \& Mohamed, H. A. (1993). Field manual of common faba bean diseases in the Nile Valley. Information Bulletin, (3). Aleppo: International Center for Agricultural Research in the Dry Areas (ICARDA).

Ceccarelli, S. (1997). Adaptation to low/high input cultivation. In Adaptation in Plant Breeding (pp. 225-236). Kluwer Academic Publishers, The Netherlands.

Central Statistical Agency of Ethiopia (CSA) (2019/20). Report on Area and Production of Major Crops (Private peasant holdings, meher season). Statistical Bulletin, Addis Ababa, Ethiopia, 1 (587): 9-17.

Dereje, A., Biru, A., \& Tashome, G. (2019). Analysis of Genotype by Environmental Interaction and Stability for Grain Yield of Faba Bean (Vicia faba L.) Genotypes in West and Kellem Wollega Zones of Western Oromia. International Journal of Research Studies in Agricultural Sciences, 5(7):37-43.

Food and Agriculture Organization Statistics (FAOSTAT). (2018). Statistical database of agricultural production. Rome, Italy.

Gomez, K. A \& Gomez, A. (1984). Statistical Procedures for Agricultural Research, $2^{\text {nd }}$ Edition. New York, NY: John Wiley \& Sons

Keneni G., Jarso M. and Wolabu T. (2006). Faba bean (Vicia faba L.) Genetics and Breeding Research in Ethiopia: A Review. In: A. Kemal et al., editors, Food and Forage legumes of Ethiopia: Progress and Prospects. Proceedings of the Workshop on Food and Forage Legumes, 22-26 September 2003, Addis Ababa, Ethiopia.Sponsors:EIAR and ICARDA. ICARDA, Aleppo, Syria. pp. 43-66.

Keneni, G., Bekele, E., Assefa, F., Debele, T., Dagne, K., \& Getu, E. (2015). Characterization

9 | This work is licensed under a Creative Commons Attribution 4.0 International License. 
of Ethiopian chickpea (Cicer arietinum L.) germplasm accessions for phosphorus uptake and use efficiency I. Performance evaluation. Ethiopian Journal of Applied Science and Technology, 6(2), 53-76.

Keneni, G., Fikre, A., \& Eshete, M. (2016). Reflections on highland pulses improvement research in Ethiopia. Ethiop. J. Agric. Sci, 1750.

Kumar, P., Das, R. R., Bishnoi, S. K., \& Sharma, V. (2017). Inter-correlation and path analysis in faba bean (Vicia faba L.). Electronic Journal of Plant Breeding, 8(1), 395-397.

Mesfin, T., Wassu, M. \& Mussa, J. (2020). Yield Stability and Genotype $\times$ Environment Interaction of Faba Bean (Vicia faba L.). International Journal of Plant Breeding and Crop Science, 7(2): 833-846.

Million, F. \& Habtam, S. (2012). Genetic Variability on Seed Yield and Related Traits of Elite Faba Bean (Vicia faba L.) Genotypes. Pakistan Journal of Biological Sciences, 15 (8), 380-385.

Million, F. (2012). Evaluations the performance of commercial faba bean (Vicia faba L.) varieties on some morpho-physiological and $\mathrm{N}$-fixing Traits under Eastern Ethiopia. International Journal of Agronomy and Agricultural Research, 8 (2): 29-43.

Mitiku, A., \& Wolde, M. (2015). Effect of Faba Bean (Vicia faba L.) Varieties on Yield Attributes at Sinana and Agarfa Districts of Bale Zone, Southeastern Ethiopia. Jordan Journal of Biological Sciences, 8(4).

Mussa, J. \& Gemechu, K. (2006). Vicia faba L. in: M. Brink, G. Belay (Eds.), Plant Resources of Tropical Africa 1: Cereals and Pulses, PROTA Foundation, Wageningen, Netherlands/Backh uys Publishers, Leiden, Netherlands/CTA, Wageningen, Netherlands, pp. 195-199.

Samuel, S., Chemeda, F., Sakhuja, P. K. \& Seid, A. (2010) Yield loss of faba bean (Vicia faba) due to chocolate spot (Botrytis fabae) in sole and mixed cropping system in Ethiopia. Archives of Phytopathology and Plant Protection, 43, 1144 -1159.
SAS Institute (2010) SAS/STAT guide for personal computers, version 9.3 edition. Cary, NC: SAS Institute Inc.

Singh, A. K., Bharati, R. C., Ch, N., \& Pedpati, A. (2013). An assessment of faba bean (Vicia faba L.) current status and future prospect. African Journal of Agricultural Research, 8(50), 66346641.

Tadele, M. (2019). Breeding achievements of faba bean (Vicia faba L.) and its impact in the livelihood of Ethiopian farmers. International Journal of Agriculture and Bioscience, 8(5): 263-269.

Tadele, M., Mohammed, W. \& Jarso, M. (2021). Variation in genetic variability and heritability of agronomic traits in Faba bean (Vicia faba L.) genotypes under soil acidity stress evaluated with and without lime in Ethiopia. African Journal of Agricultural Research, 17(2): 355-364.

Tadele, M., Mohammed, W., \& Jarso, M. (2019). Genetic variability on grain yield and related agronomic traits of faba bean (Vicia faba L.) genotypes under soil acidity stress in the central highlands of Ethiopia. Chemical and Biomolecular Engineering, 4(4), 52-58.

Tamene, T., Gemechu, K., \& Hussein, M. (2015). Genetic progresses from over three decades of faba bean (Vicia faba L.) breeding in Ethiopia. Australian Journal of Crop Science, 9(1):4148.

Tekalign, A., Derera, J., \& Sibiya, J. (2020). Phenotypic Diversity among Faba Bean (Vicia faba L) Landraces from the Ethiopian Highlands. Ethiopian Journal of Agricultural Sciences, 30(1), 17-34.

Tekalign, A., Derera, J., Sibiya, J., \& Fikre, A. (2016). Participatory assessment of production threats, farmers' desired traits and selection criteria of faba bean (Viciafaba L.) varieties: opportunities for faba bean breeding in Ethiopia. Indian Journal of Agricultural Research, 50(4), 295-302.

Tekle, E. K., Raghavaiah, C. V. \& Ibrahim, H. (2016). Production potential of faba bean (Vicia faba L.) genotypes in relation to plant densities and phosphorus nutrition on vertisols of central highlands of west showa zone,

10 | This work is licensed under a Creative Commons Attribution 4.0 International License. 
Ethiopia, East Africa. Advances in Crop Science and Technology, 2(4): 1-9.

Tewodros, T., Asfaw, A., Getachew, T., Kibersew, M. \& Samuel, S. (2015). Evaluation of Faba bean (Vicia faba L.) varieties against chocolate spot (Botrytis fabae) in North Gondar, Ethiopia. African Journal of Agricultural Research, 10(30):2984-2988.

11 This work is licensed under a Creative Commons Attribution 4.0 International License. 